\title{
EMPLOYEE PERCEPTION OF THE IMPACT OF INFORMATION TECHNOLOGY INVESTMENT IN ORGANISATIONS: A SURVEY OF THE HOTEL INDUSTRY
}

\author{
Bruce W.N. Lo \\ School of Multimedia \& Information Technology \\ Southem Cross University, Lismore, NSW Australia 2480 \\ Email: blo@scu.edu.au \\ Gede Sri Darma \\ Pendidikan National University (UNDIKNAS) \\ Jl. Tukad Yeh Aya P O Box 2361, Denpasar, Bali (80225) Indonesia \\ Email: sridarma@indo.net.id
}

\begin{abstract}
To improve their operational efficiency and to maintain their competitiveness in the market place many organisations continue to invest substantially in their Information Technology (IT) capability. But how do the employees themselves view the impact and the value of IT investment? This paper considers this question in the context of the hospitality industry. More specifically, it investigates the different perception of hotel employees on the impact of organisational IT investment on (a) IT usage by employees, (b) employee satisfaction with the IT systems, (c) changes in the level of employee performance, and (d) organisational performance of the hotel.

945 hotel employees in Bali, Indonesia were surveyed to assess their perception of the organisational impact of IT. Factor analysis, analysis of variance and regression analysis were performed on the data to examine the range of employee viewpoints. Results showed that there were significant differences among the employees' perception with respect to age, educational level, position in the hotel, and individual income. These findings suggest that even senior management may regard the investment in $\mathrm{IT}$ is worthwhile, there may be a divergence of opinion among the employees as to what are the real benefits of IT. In order to fully leverage the potential of their IT investment, managers should pay particular attention to shaping the views of the employees who ultimately determine whether the IT capabilities in an organisation are put to use.
\end{abstract}

\section{INTRODUCTION}

The impact of information technology (IT) investment in organizations has received considerable attention in the literature during the past few years (Kauffman \& Weill, 1989; Harris \& Katz, 1991; Weill, 1992a; 1992b; Wilcox, 1994; Raymond et al., 1995; Byrd \& Marshall, 1997; Sriram et al., 1997; Sohal \& Ng, 1998). On the one hand IT is seen as the enabling agent through which organisations can improve their operational efficiency and strategic position in an increasing competitive business environment. On the other hand, in the current economic climate, many are questioning the real benefits of the ever increasing IT investment in the organization.

Past research on the impact of IT investment on organisational performance has been rather inconclusive. Research literatures do not give reliable generalisation about the relationships between IT investment and organisational changes (Powell \& Dent-Micallef, 1997; Fitzgerald, 1998). Some studies found a positive relationship between the two, while other actually found no relationship at all. It is generally believe that there are other factors, which come into play.

Unfortunately, too often the decision to invest was made based on fear of being left behind by competitors rather than on a genuine understanding of the real benefits that IT can bring to the organisation (Weill 1992a). This lack of understanding can lead to the organisation's inability to generate a shared vision among employees on how to leverage the real potential of IT in that organisation. Consequently the huge investment in IT committed by the organisation sometime did not produce the full benefits that was expected at the time when the decision to invest was made. The purpose of this study is to examine the different employee's perceptions and expectations of the impacts of IT investment on the organisation, and to develop an instrument to measure these perceptions. It is hoped that the findings will assist senior management to have a more realistic approach in making decisions on organisational investments in IT and the associated expectation of the likely benefits. The findings will also provide some insights to senior management as to how to harness the human elements of the organisational information system to ensure that the technological capabilities of the system are fully utilised.

In this study, the hotel industry was chosen as the subject of investigation. There are several reasons for this choice. Firstly to the best knowledge of the authors, this industry has not been the central subject of study in this research area. Secondly, during the last few years hotels have become increasingly dependent on computer and communications technology to manage the diverse range of service provision, needed in a highly competitive and globalised market.

Instead of conducting the study in a technologically developed country, the authors have chosen to study the organisational impact on hotels at a regional location, viz. Bali, Indonesia, which is considered as a part of the developing region of the world with rapidly changing national information infrastructure. But in terms of tourist demand, Bali is no less significant than any other international destinations. Hence the need of technology support to maintain a highly competitive customer service is just as real as in other parts of the world. This challenge is clearly recognised by the local tourism authority (Mardani, 1997).

The remainder of this paper is organized into seven sections. The next (second) section begins with a brief review of previous research in this area. The third section provides a brief description of the research methodology employed in this study. Descriptive data analysis, and the reliability and validity of the instrument are reported in the fourth section. The demographic differences on employee perception are examined in the fifth section. Finally the different perceptions by employees of the impacts of information technology investment in the organisation are reported in the sixth section. 
The paper concludes with a discussion on the implications of these findings for management.

\section{PREVIOUS RESEARCH}

Given the high level of financial stakes involved, the investigation on the impact of information technology investments on organisational performance and organisational processes has been and continues to be a major research concern for practitioners and academics (Willcocks, 1996). Previous studies have evolved from early anecdotal reports to more recent empirically-based rescarch (e.g. Sriram et al., 1997). They also covered a wide range of perspectives including investigation on research methodologies (Orlikowski \& Baroudi, 1991), the extent of IT use (Weill 1992b), the concept of organisational performance and business value (Mukhopadhyay et al., 1995), the strategic advantage of the firm (Weill, 19992a, Mata et al., 1995), the impact on inter-organisational relationships, the impact on the management function and its structure, the change in organisation's work environment, and even the very nature of the organisation's core business in the marketplace (Willcocks, 1994).

The relationship between IT and the organisation is multi-facet and highly complex. The impact of IT investment in organisations is far reaching, and may affect not only the internal attributes but also the external attributes of a firm. Attempts to a isolate particular aspect of the relationship often lead to different or even seemingly contradictory results. For example, a careful review of research studies on the impact of organisational IT investment on organisational performance is likely to result in an inconclusive view of the relationship, as studies reported both positive and negative impacts, as well as no relationship at all.

To highlight the diverse perspectives on this relationship, three tables are presented which provide a summary on the findings of major studies by different researchers on this issue. Table 1 summarises those studies, which yielded a positive relationship.

Table 1: Studies showing positive relationship between IT investment and organisational performance

\begin{tabular}{|c|c|c|}
\hline References & Industry & Key variables and key findings \\
\hline Bender (1986) & Insurance & $\begin{array}{l}\text { Optimum level of performance achieved at a range of IT investment from } \\
15 \% \text { to } 25 \% \text { of total operating cost of the firm. }\end{array}$ \\
\hline $\begin{array}{l}\text { Banker, } \\
\text { Kauffman \& } \\
\text { Morey (1990) }\end{array}$ & $\begin{array}{l}\text { Fast } \quad \text { Food } \\
\text { stores }\end{array}$ & $\begin{array}{l}\text { Stores with the technology and large breakfast sales (more complex } \\
\text { breakfast menu) performed significantly better in terms of cutting } \\
\text { materials handling costs. }\end{array}$ \\
\hline $\begin{array}{l}\text { Harris \& Kats } \\
(1991)\end{array}$ & Insurance & $\begin{array}{l}\text { Firms with the most improvement in organisational performance allocated } \\
\text { a significantly higher proportion of their non-interest operating expenses } \\
\text { to IT. }\end{array}$ \\
\hline Weill (1992b) & $\begin{array}{l}\text { Valves } \\
\text { manufacturing }\end{array}$ & $\begin{array}{l}\text { Transactional IT investment correlated positively with organisational } \\
\text { performance }\end{array}$ \\
\hline $\begin{array}{l}\text { Santos, Peffers \& } \\
\text { Mauer (1993) }\end{array}$ & $\begin{array}{l}\text { Finance and } \\
\text { manufacturing }\end{array}$ & $\begin{array}{l}\text { Market value of the firm reacted positively to the announcements of IT } \\
\text { investment by the organisations. }\end{array}$ \\
\hline Mahmood (1994) & $\begin{array}{l}81 \text { firms from } \\
\text { Computerworl } \\
d \text { in a non- } \\
\text { random } \\
\text { sample }\end{array}$ & $\begin{array}{l}\text { Firms in the efficient group had a much higher return on their IT } \\
\text { investment than the inefficient group. }\end{array}$ \\
\hline $\begin{array}{l}\text { Raymond, Pare \& } \\
\text { Bergeron (1995) }\end{array}$ & Manufacturing & $\begin{array}{l}\text { IT usage is positively related to organisational performance and the } \\
\text { relationship between IT management and structural sophistication is } \\
\text { stronger among the better performing firms. }\end{array}$ \\
\hline $\begin{array}{l}\text { Lubbe, Parker \& } \\
\text { Hoard (1995) }\end{array}$ & Insurance & $\begin{array}{l}\text { Positive relationship found between the computerisation index and the } \\
\text { financial ratios; the most profitable firms were more likely to spend a } \\
\text { higher proportion of the non-interest operating expenses on IT. }\end{array}$ \\
\hline $\begin{array}{l}\text { Siram, Stump \& } \\
\text { Banerhee (1997) }\end{array}$ & Purchasing & $\begin{array}{l}\text { Positive relationship was found: IT used in purchasing is not a } \\
\text { homogenous phenomenon, but can be represented by three components- } \\
\text { basic computer systems \& support, purchasing-specific applications, and }\end{array}$ \\
\hline
\end{tabular}




\begin{tabular}{|l|l|l|}
\hline & vender communications. \\
\hline $\begin{array}{l}\text { Rai, Patnayakuni } \\
\text { \& Panayakuni } \\
(1997)\end{array}$ & Purchasing & $\begin{array}{l}\text { IT investment made a positive contribution to the firm's output and labor } \\
\text { productivity. }\end{array}$ \\
\hline
\end{tabular}

Table 2 summarises those studies which gave a negative relationship. Finally, Table 3 lists those studies where the authors found no relationship exists between IT and organisational performance. For other recent reviews on the subject, readers are referred to the articles by Powell \& Dent-Micalleff (1997), Mahmood (1997), and Sohal \& Ng (1998).

Table 2: Studies showing negative relationship between IT investment and organisational performance

\begin{tabular}{|c|c|c|}
\hline References & Industry & Key variables and key findings \\
\hline $\begin{array}{l}\text { Cron \& Sobol } \\
(1983)\end{array}$ & Warehousing & $\begin{array}{l}\text { Firms that make extensive use of computer have either a very strong or a } \\
\text { very week financial performance. }\end{array}$ \\
\hline Roach (1988) & Finance & $\begin{array}{l}\text { IT investment had negative and dysfunctional effects on organisational } \\
\text { performance. }\end{array}$ \\
\hline $\begin{array}{l}\text { Kauffman \& } \\
\text { Weill (1989) }\end{array}$ & $\begin{array}{l}\text { Valves } \\
\text { manufacturing }\end{array}$ & Very little evidence of the value contributed by IT investments. \\
\hline Weill (1992b) & $\begin{array}{l}\text { Valves } \\
\text { manufacturing }\end{array}$ & $\begin{array}{l}\text { Strategic IT investment had a negative relationship to organisational } \\
\text { performance }\end{array}$ \\
\hline $\begin{array}{l}\text { Hitt and } \\
\text { Brynjolfsson } \\
(1996)\end{array}$ & Finance & $\begin{array}{l}\text { Small negative relationship between computer capital and total } \\
\text { shareholder return in at least one year. }\end{array}$ \\
\hline
\end{tabular}

Table 3: Studies showing no relationship between IT investment and organisational performance

\begin{tabular}{|l|l|l|}
\hline \multicolumn{1}{|c|}{ References } & \multicolumn{1}{|c|}{ Industry } & \multicolumn{1}{c|}{ Key variables and key findings } \\
\hline Turner (1985) & Banking & $\begin{array}{l}\text { No relationship was found between organisational performance and the } \\
\text { relative proportion of resources allocated to data processing. }\end{array}$ \\
\hline $\begin{array}{l}\text { Strassmann } \\
\text { (1985) }\end{array}$ & $\begin{array}{l}\text { Service sector } \\
\text { firms }\end{array}$ & $\begin{array}{l}\text { No significant relationship was found between high performing firms and } \\
\text { the size of IT investment. }\end{array}$ \\
\hline $\begin{array}{l}\text { Santos, Peffers \& } \\
\text { Mauer (1993) }\end{array}$ & $\begin{array}{l}\text { Finance and } \\
\text { manufacturing }\end{array}$ & $\begin{array}{l}\text { No excess returns was found for either the full sample or for any one of } \\
\text { the industry subsamples. }\end{array}$ \\
\hline $\begin{array}{l}\text { Powell and Dent- } \\
\text { Micallef (1997) }\end{array}$ & Retail industry & IT alone had not produced sustainable performance advantages. \\
\hline
\end{tabular}

Recognising the complexity of the issues under consideration, some authors attempted to investigate the intervening factors in the IT investment-organisational performance relationship. Floyd and Wooldridge (1990) examined the evidence of $\mathrm{IT}$ investment having a moderating effect on the organisational competitive strategy and financial performance. On the other hand, Parthasarthy and Sethi (1993) investigated how strategy and structure moderate the relationship between capital outlay in computer automation and firm performance. In their study, they found that the flexibility of business and manufacturing strategies, quality of leadership, and cost leadership had a significant moderating effect. More recently, Sohal and $\mathrm{Ng}$ (1998), in their study of 530 companies in the Australian manufacturing, banking and finance, and insurance industries, found that the greatest impediments in unleashing the full potential of IT in an organisation are the misalignment of business and IT strategies, lack of change in historic IT structure, lack of a full understanding of the potential of IT, and lack of senior management support.

In the context of these findings, the present study attempts to go beyond simple financial measures of organisational performance and consider a number of user-organisation variables as perceived by the employees which may be affected 
by the organisational investment in IT. Therefore, as well as examining the employees' (in their roles as the user of the IT systems) perceptions on the organisation performance, this study also probe their perception on (a) user satisfaction with the organisational information system, (b) the level of IT usage and (c) the effect of IT on employee performance. The basic premise is that, the employees' perception of the benefit of IT investment plays an important role in determining whether the investment itself will lead to actual improvements in organisational performance.

\section{METHODOLOGY}

This study follows the survey research methodology. Based on previous research in related areas, a questionnaire was constructed to measure the perceptions of the employees on each of the following five variables:

- the level of information technology investment (ITI) by the organisation,

- the amount of information technology usage (ITU) in the organisation,

- the level of user satisfaction (US) with the organisational information system,

- the level of employee performance (EP), and

- the level of organisational (in this case the hotel) performance (HP).

After pilot testing, the questionnaire was administered to a group of subjects consisting of the employees in twenty 4 and 5-star hotels in Bali, Indonesia. The data were analysed using standard techniques of factor analysis, analysis of various and multiple regression to examine the different employee perceptions on these variables. The remainder of this section gives a brief description of the sample, the survey instrument and the survey procedure.

\section{Sample}

The target group chosen for this study, were hotel employees in Bali, Indonesia, who regularly used computers in the performance of their duties. They include those working at both the front counters and at the back offices as well as people in management positions. In addition to standard hotel reservation and accounting, these employees used a variety of computerised applications in their daily work. It is thought that the different employment situations will provide a wider and more representative viewpoint in the survey.

Only hotels with 5- and 4-star rating were chosen rather than the lower ranking hotels, because typically hotels in the former group are better equipped with IT facilities and they tend to cater for international tourists. A larger proportion of employees in these hotels was supplied with PCs. All PCs and minicomputers in the hotels surveyed in this study were connected to the corporate computer network.

\section{Survey Instrument}

A four-page questionnaire consisting of six subscales was developed. In the first subscale, demographic information such as age, gender, marital status, position in hotel, educational background, and individual income level were sought. In the remaining five subscales, questions were adapted from similar instruments reported in the literature by previous researchers, to measure the perception of the subjects on the five variables under consideration, viz. information technology investment by the organisation (ITI), information technology usage by employees (ITU), user satisfaction with the IT facilities (US), level of employee performance (EP) and level of hotel performance (HP). The structure of the questionnaire is summarised in Table 4. The main references on which the subscales are based or adapted are also indicated in the table.

Each question in the last five subscales of the questionnaire was scored on an 11 -point Likert scale ranging from (0) "not at all/almost never" to (10) "extremely large/almost always". The two "frequency" questions in the ITU subscale, naturally involve counting of the number of applications and is not based on the Likert rating scale. 
Table 4: Structure of the Questionnaire

\begin{tabular}{|c|c|c|c|}
\hline Subscale & What it measures & Key elements of the questions & Source references \\
\hline $\begin{array}{c}1 \\
\text { DEMO }\end{array}$ & Demographics & $\begin{array}{l}\text { Age } \\
\text { Gender } \\
\text { Marital status } \\
\text { Position in Hotel } \\
\text { Educational background } \\
\text { Income level }\end{array}$ & \\
\hline $\begin{array}{c}2 \\
\text { ITI }\end{array}$ & $\begin{array}{l}\text { Information } \\
\text { technology } \\
\text { investment }\end{array}$ & $\begin{array}{l}\text { Hardware investment } \\
\text { Software investment } \\
\text { Training costs } \\
\text { Support costs } \\
\text { Total investment } \\
\end{array}$ & $\begin{array}{l}\text { Sriram, Stump \& Banerhee } \\
\text { (1997) }\end{array}$ \\
\hline $\begin{array}{c}3 \\
\mathrm{HP}\end{array}$ & Hotel performance & $\begin{array}{l}\text { Hotel financial performance } \\
\text { Hotel room occupancy } \\
\text { Number of visitors }\end{array}$ & Jeffrey \& Hubbard (1994) \\
\hline $\begin{array}{c}4 \\
\text { ITU }\end{array}$ & $\begin{array}{l}\text { Information } \\
\text { technology usage }\end{array}$ & $\begin{array}{l}\text { Frequency of use } \\
\text { Time of use } \\
\text { Criticality of use } \\
\text { Feeling of use } \\
\text { Number of business task used } \\
\text { Number of computerised applications }\end{array}$ & $\begin{array}{l}\text { Straub, Limayem \& } \\
\text { Karahanna-Evaristo (1995); } \\
\text { Igbaria \& Tan (1997) }\end{array}$ \\
\hline $\begin{array}{c}5 \\
\text { US }\end{array}$ & User satisfaction & $\begin{array}{l}\text { Provide precise information } \\
\text { Information content meet need } \\
\text { Provide reports needed } \\
\text { Sufficient information } \\
\text { Computer system accurate } \\
\text { Satisfied with accuracy } \\
\text { Output in useful format } \\
\text { Information clear } \\
\text { User friendly } \\
\text { Ease of use } \\
\text { Information on time } \\
\text { Up to date information }\end{array}$ & Doll \& Torkzadeh (1988) \\
\hline $\begin{array}{c}6 \\
\mathrm{EP}\end{array}$ & $\begin{array}{l}\text { Employee } \\
\text { performance }\end{array}$ & $\begin{array}{l}\text { Productivity } \\
\text { Job performance } \\
\text { Effectiveness of the job } \\
\text { Decision making quality }\end{array}$ & Igbaria \& Tan (1997) \\
\hline
\end{tabular}

\section{Information Technology Investment}

To measure information technology investment, it is not sufficient to consider the total cost of IT equipment. Sriram et al. (1997) pointed out that, in addition to hardware, software and telecommunications costs, there are other costs associated with the support and operation of IT facilities in an organisation. This study identified four components: computer hardware cost; computer software cost; the cost of training IT users; and the cost of supporting IT users during normal operation. Telecommunication costs have been absorbed into the other components. The authors believe that by measuring each of these separately provides a more complete and reliable picture on the organisational IT investment. Information Technology Usage

Several researchers (Straub et al., 1995; Igbaria \& Tan, 1997) have reported instruments with reliability $\bullet=0.7$ or higher to measure information technology usage. From their works, six measures were chosen to be used in this study: (i) frequency of use; (ii) time of use; (iii) criticality of IT usage; (iv) feeling of IT usage; (v) number of business tasks for which the system was used by employees; and (vi) number of computerized applications used by employees. A mixture of semantic differential scales and Likert-type scales was used to record responses to the survey questions. The number of business tasks involving the computer and the number of different computer applications used were employed as an indication of the extent of IT usage.

\section{User Satisfaction}

Delone and McLean (1992) argued that user satisfaction occupies a key role in information system success. In the present study, user satisfaction is taken to mean the employees' attitude towards the use of computer facilities as they 
perform their daily duties in the hotel. The scale, developed by Doll and Torkzadeh (1988) with $\bullet=0.8$, was adapted here to measure the overall user satisfaction that includes a measure of the extent to which organisational information systems meet the end-user's needs with regards to information content, accuracy, timeliness, format and ease of use.

\section{Employee Performance}

Employee performance was measured based on a scale developed by Igbaria and Tan (1997) $(\alpha=0.8)$. What is being measured here is the employees' perception of their own performance improvement (or the lack of it) in four indicators as a result of the use of IT facilities. The four indicators are (i) productivity on the job, (ii) job performance, (iii) effectiveness on the job, and (iv) decision-making quality.

\section{Hotel Performance}

Organisational performance is a complex phenomenon. Any finite set of measures for hotel performance is likely to be too simplistic. Financial indicators alone are not sufficient to capture the broad scope of hotel performance. Therefore three different global measures were chosen in this study: (i) hotel financial performance; (ii) room occupancy rate; and (iii) the number of visitors. This set of measures provides a performance profile in terms of occupancy and visitation rate as well as financial performance. It was found to be a better indicator of the overall performance of hotels (Jeffrey and Hubbard, 1994).

\section{Survey Procedures}

The instrument was first pilot tested on a small group of 12 hotel employees selected from Lismore and Gold Coast areas in Australia and from Bali in Indonesia. Preliminary analysis of the pilot data showed that those completed the survey form were generally happy with the questions asked. Minor changes were made to the item statements to improve clarity of presentation.

Prior to the conduct of the full survey in 1998, the approval and support of the Director of the Department of Tourism, Post, and Telecommunication at Bali was obtained. As a result, the researchers were able to claim official sanction and legitimacy of the rescarch project, thus improving the response rate. To assist with the data collection process, the Department also provided useful information on the addresses of the twenty-eight 4- and 5-star hotels in Bali, their phone and facsimile numbers, the names of the hotel general manager, the number of employees, and the number of rooms in each hotel.

With a letter of introductory from the Bali Tourism Director, initial telephone contacts were made with the General Manager of all 28 hotels in Bali, and permission was sought to conduct a survey in their hotels. Out of the 28 hotels, twenty were willing to participate in the study representing $71 \%$ of the population group (in hotel counts). It is believed that this should provide an adequate sample of the target population. These 20 hotels employ a total of 11,529 employees. Of these, 1,131 or approximately $10 \%$ used computers directly in their daily duties.

Questionnaire forms were then hand-delivered to these 20 hotels for distribution to the 1,131 employees. The survey package consists of a 4-pages questionnaire, a covering letter, a guide on how to fill the questionnaire, and the letter of introduction from the Director of the Bali Department of Tourism, Post and Telecommunication. Hotel General Managers who had agreed to participate were urged strongly to encourage their employees to complete the questionnaire. As an incentive, a souvenir key ring from Australia was offered as a token of appreciation to all those employees who have returned a completed questionnaire, a gesture that proved to be very popular.

To ensure a degree of objectivity in the survey data, selected employees were personally interviewed by the researchers to verify the accuracy of the self-reported data. As far as the researchers were able to ascertain, the self reported data were found to be reliable.

\section{DATA ANALYSIS}

The data collected from the survey were scored and entered in the computer for analysis by the SPSS package. Some preliminary results relating to the sample characteristics, the reliability of the questionnaire, and the validity of the measures are reported in this section.

\section{Respondent characteristics}

Of the 1,131 questionnaire forms distributed, 945 completed forms were returned, representing a response rate of $83 \%$, which is considered an acceptable level of response in this type of research. Listed in Table 5 are the $\mathbb{D}$ of the hotels that participated (names were suppressed for confidentiality), the number of employees in each, the number of completed questionnaires returned, and the number of persons interviewed for validation purpose. 
Table 5: Questionnaire Response Rates

\begin{tabular}{|c|c|c|c|c|c|c||}
\hline Hotel ID. & $\begin{array}{c}\text { Star } \\
\text { Level }\end{array}$ & $\begin{array}{c}\text { Total } \\
\text { employees }\end{array}$ & $\begin{array}{c}\text { IT end-user } \\
\text { employees }\end{array}$ & $\begin{array}{c}\text { Questionnair } \\
\text { es returned }\end{array}$ & $\begin{array}{c}\text { Percentage } \\
\text { of returns }\end{array}$ & $\begin{array}{c}\text { Persons } \\
\text { interviewed }\end{array}$ \\
\hline 1 & 5 & 985 & 90 & 80 & $88.9 \%$ & 5 \\
2 & 5 & 804 & 78 & 61 & $78.2 \%$ & 4 \\
3 & 5 & 784 & 80 & 60 & $75.0 \%$ & 4 \\
4 & 5 & 773 & 70 & 55 & $78.6 \%$ & 4 \\
\hline 5 & 5 & 758 & 76 & 60 & $78.9 \%$ & 4 \\
6 & 5 & 751 & 75 & 71 & $94.7 \%$ & 4 \\
7 & 5 & 717 & 100 & 78 & $78.0 \%$ & 5 \\
8 & 5 & 708 & 55 & 35 & $63.6 \%$ & 3 \\
\hline 9 & 5 & 693 & 60 & 56 & $93.3 \%$ & 3 \\
10 & 5 & 670 & 70 & 62 & $88.6 \%$ & 4 \\
11 & 5 & 628 & 40 & 36 & $90.0 \%$ & 2 \\
12 & 5 & 592 & 55 & 50 & $90.9 \%$ & 3 \\
\hline 13 & 5 & 580 & 60 & 55 & $91.7 \%$ & 3 \\
14 & 5 & 418 & 40 & 32 & $80.0 \%$ & 2 \\
15 & 5 & 386 & 40 & 35 & $87.5 \%$ & 2 \\
16 & 4 & 309 & 30 & 28 & $93.3 \%$ & 2 \\
\hline 17 & 4 & 292 & 30 & 25 & $83.3 \%$ & 2 \\
18 & 4 & 234 & 30 & 24 & $80.0 \%$ & 2 \\
19 & 4 & 227 & 27 & 22 & $81.5 \%$ & 1 \\
20 & 4 & $\mathbf{2 2 0}$ & 25 & 20 & $80.0 \%$ & 1 \\
\hline Total/Ave & & $\mathbf{1 1 , 5 2 9}$ & $\mathbf{1 , 1 3 1}$ & $\mathbf{9 4 5}$ & $\mathbf{8 3 . 6 \%}$ & $\mathbf{5 7}$ \\
\hline
\end{tabular}

An examination of the individual response rate for each hotel, all except Hotel No. 8, have a response rate of $75 \%$ or above. Even in the lowest case, the response rate is $63.6 \%$. Therefore, the data collected may be considered a reasonable representation of all the IT end-user employees in these hotels.

The biographical characteristics of the respondents in this survey are summarised in Figures 1 to 6.

With respect to age (Figure 1), the majority of the employees surveyed were relatively young (70.6\% of the respondents fell in the age range of $25-40$ ). The mean age of the respondents was 34 . It is generally believed that younger workers are

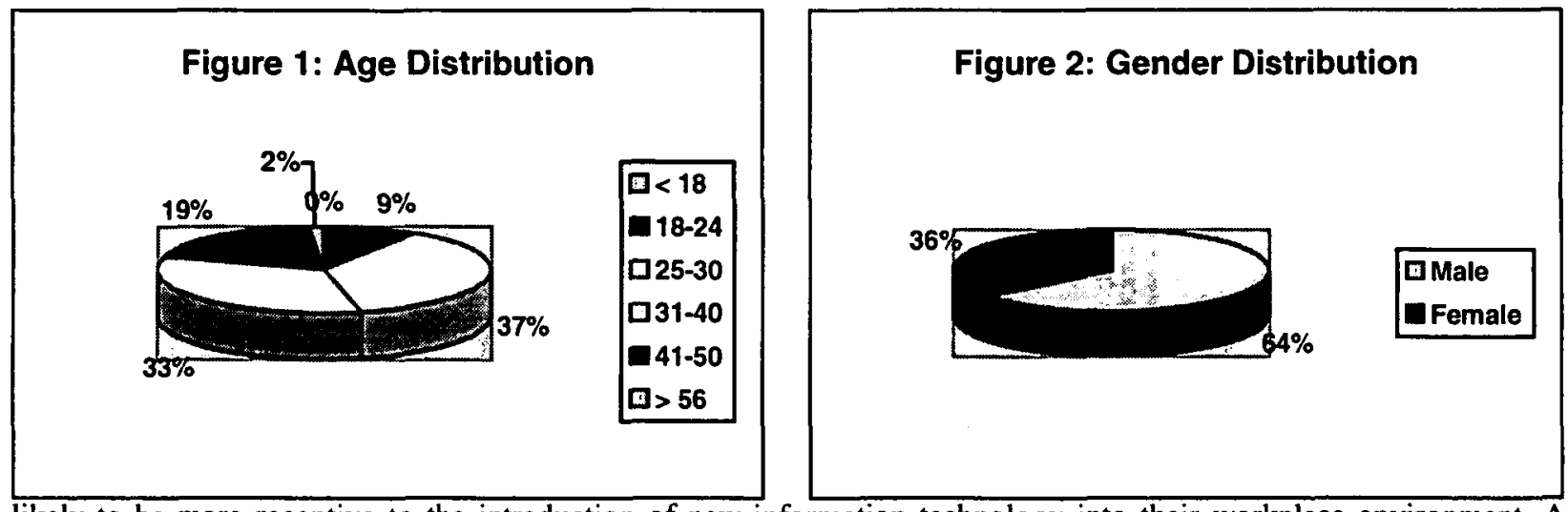

likely to be more receptive to the introduction of new information technology into their workplace environment. As shown in Figure 2, the majority of the respondents, $64 \%$ were male and only $36 \%$ were female. This gender distribution reflects the typical trend of the workforce in Indonesia.

Figure 3: Position in Hotel

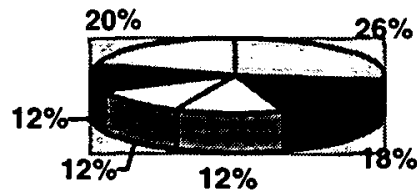

\begin{tabular}{|l|}
\hline Account \\
Reception \\
$\square$ Staffing \\
$\square$ Info Sys \\
Marketing \\
OOthers \\
\hline
\end{tabular}

\section{Figure 4: Educational Level}

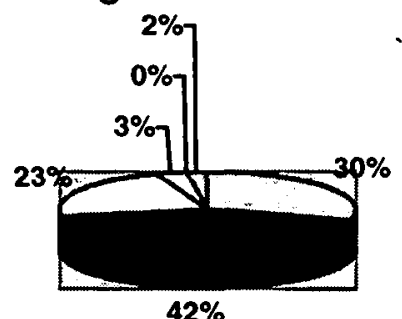

\begin{tabular}{|l|}
\hline High Sch \\
Diploma \\
$\square$ Bachelor \\
$\square$ Master \\
Doctorate \\
OOthers \\
\hline
\end{tabular} 
As for the nature of their employment positions, the largest group of respondents (27\%, See Figure 3) were working in the accounting and finance sections of the hotel, signifying that this job function is probably the most computerised group in the hotel. The second largest group of subjects worked in the front office. It is interesting to note that a significant proportion (20.4\%) of the respondents worked in others departments such as engineering, executive office, banqueting, food and beverage, kitchen, laundry, housekeeping, material, and time keeping. This seems to indicate that the application of information technology is reasonably wide spread among these hotels.

Figure 4 shows the educational levels of the subjects. Over two-thirds of the hotel employees participated in this survey (68\%) have at least either a tertiary diploma or university degree. About $30 \%$ have only completed high school education. The trend of the hospitality industry in employing more professionally trained workers was evident here.

In terms of the monthly income level (Figure 5), the largest group (53.7\%) fell in the range $\mathrm{Rp} .500,001$ to $\mathrm{Rp}$. $1,000,000$, while a further $40.7 \%$ was remunerated at a higher level. According to Statistics Office of Bali Province

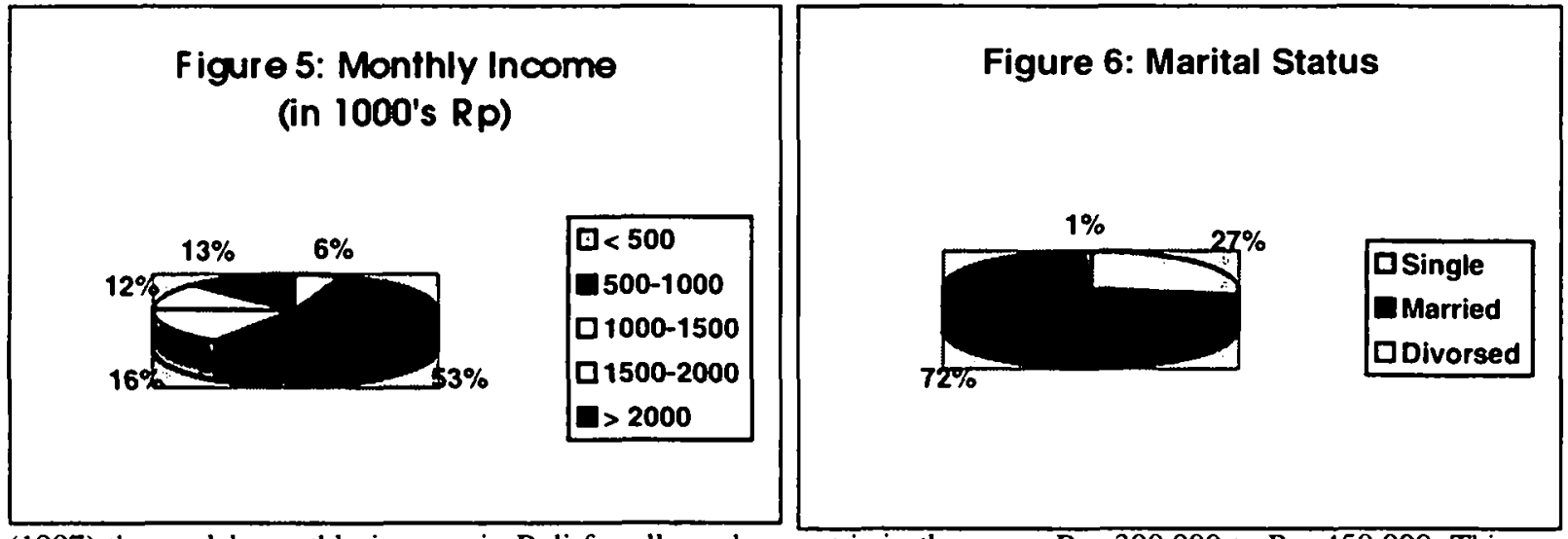

(1997) the modal monthly income in Bali for all employment is in the range Rp. 300,000 to Rp. 450,000. This means that the people employed in the hospitality industry enjoyed a much higher level of pay compare to all employment groups. Finally Figures 6 lists the marital status of the respondents.

\section{Reliability of the Scale}

Table 6 gives the descriptive statistics: means, standard deviation and factor loading (to be discussed later) for each item in the questionnaire. It is noted that all items were found to have a mean value ranging from 7.7 to 9.1 in the 11 -point scale, where a value of 5 is regarded as the neutral point. This indicates that the ratings from the respondents tend to lie on the positive side of the rating scale. Furthermore, the standard deviations were found to range from 0.81 to 1.49 . indicating a relatively high degree of consensus among the respondents in their perception of the rating of the five variables in question.

Factor analysis was carried out on each of the five research variables with respect to items in the questionnaire. In each case only one factor was identified, accounting for $74 \%$ to $84 \%$ of the variance in the set of questionnaire items. The Factor loading for each item is shown in Table 6 . The homogeneity of the factor loading coefficients is to be expected as most items are adapted from other similar instruments.

To assess the reliability of the instrument, the Cronbach (1981) alpha coefficients for the total questionnaire and the five subscales were calculated and reported in Table 7. The Cronbach alpha is the most widely used index for determining internal consistency (Kerlinger, 1986). It has been generally accepted that in the early stages of research on hypothesized measures of a construct, reliabilities of 0.70 or higher are needed, while for widely used scales, the reliabilities should not be below 0.80 (Nunnally, 1978). In the current survey, all subscale alpha coefficients exceed 0.90 with an overall alpha value of 0.94 for the entire questionnaire. The high alpha value in all five subscales confirms the homogeneity of the items comprising them, and indicates an acceptable level of reliability. 
Table 6: Descriptive Statistics for the five variables (ITI, ITU, US, EP and HP)

\begin{tabular}{|c|c|c|c|c|}
\hline Code & Variables & $\begin{array}{c}\text { Factor } \\
\text { Loading }\end{array}$ & $\begin{array}{c}\text { Mean } \\
\text { (Scale 0-10) }\end{array}$ & $\begin{array}{c}\text { Standard } \\
\text { Deviatio } \\
\mathbf{n}\end{array}$ \\
\hline ITI-1 & Hardware computer investment & 0.93 & 8.19 & 1.35 \\
\hline ITI-2 & Software computer investment & 0.94 & 8.18 & 1.35 \\
\hline ITI-3 & Training cost of using Information Technology & 0.82 & 7.76 & 1.50 \\
\hline ITI-4 & Job support cost of using Information Technology & 0.90 & 8.07 & 1.41 \\
\hline ITI-5 & Total investment in Information Technology & 0.91 & 8.15 & 1.34 \\
\hline HP-1 & Hotel financial performance & 0.79 & 8.11 & 1.24 \\
\hline HP-2 & Hotel occupancy room & 0.95 & 7.91 & 1.20 \\
\hline $\mathrm{HP}-3$ & The number of visitors & 0.96 & 7.93 & 1.21 \\
\hline ITU-1 & Frequency of use & 0.90 & 9.03 & 0.84 \\
\hline ITU-2 & Time of use & 0.90 & 8.79 & 0.83 \\
\hline ITU-3 & Critical of IT usage & 0.92 & 9.06 & 0.85 \\
\hline ITU-4 & Feeling of IT usage & 0.92 & 9.11 & 0.82 \\
\hline ITU-5 & Number of business tasks using IT & 0.77 & 9.15 & 1.13 \\
\hline ITU-6 & Number of computerized applications & 0.73 & 8.54 & 0.99 \\
\hline US-1 & Provide precise information & 0.92 & 8.60 & 1.07 \\
\hline US-2 & Information content meet your need & 0.91 & 8.53 & 1.10 \\
\hline US-3 & Provide reports what you need & 0.89 & 8.60 & 1.11 \\
\hline US-4 & Provide sufficient information & 0.91 & 8.51 & 1.12 \\
\hline US-5 & Computer system accurate & 0.90 & 8.55 & 1.10 \\
\hline US-6 & Satisfied with the accuracy & 0.90 & 8.64 & 1.10 \\
\hline US-7 & The output in an useful format & 0.93 & 8.61 & 1.05 \\
\hline US-8 & The information clear & 0.94 & 8.62 & 1.07 \\
\hline US-9 & System user friendly & 0.87 & 8.42 & 1.23 \\
\hline US-10 & Ease of use & 0.87 & 8.53 & 1.10 \\
\hline US-11 & Information need on time & 0.89 & 8.55 & 1.12 \\
\hline US-12 & Up to date information & 0.85 & 8.49 & 1.21 \\
\hline EP-1 & Productivity & 0.90 & 8.32 & 1.36 \\
\hline EP-2 & Job performance & 0.95 & 8.30 & 1.32 \\
\hline EP-3 & Effectiveness of the job & 0.91 & 8.42 & 1.29 \\
\hline EP-4 & Decision making quality & 0.85 & 8.30 & 1.32 \\
\hline
\end{tabular}

Table 7: Cronbach's Alpha Coefficient of Reliability

\begin{tabular}{|l|l|c||}
\hline \multicolumn{1}{|c|}{ Name of Subscale } & \multicolumn{1}{|c||}{ Variable Code } & $\begin{array}{c}\text { Reliability } \\
\text { (Cronbach's Alpha ) }\end{array}$ \\
\hline $\begin{array}{l}\text { Information Technology Investment } \\
\text { (ITI) }\end{array}$ & ITI1 - ITI5 (5items) & 0.938 \\
\hline Hotel Performance (HP) & HP1 - HP3 (3 items) & 0.920 \\
\hline Information Technology Usage (ITU) & ITU1 - ITU6 (6 items) & 0.934 \\
\hline User Satisfaction (US) & US1 - US12 (12 items) & 0.970 \\
\hline Employee Performance (EP) & EP1 - EP4 (4 items) & 0.938 \\
\hline ENTIRE QUESTIONNAIRE & All 30 items & 0.939 \\
\hline
\end{tabular}

\section{Validation of the Perception Measures}

In using perception rating to assess user-organisation variables, a reasonable question to ask is whether the employee's perception is an accurate measure of the reality? For example, how much one can rely on the employee's perception to measure the organisation's actual investment on IT? or to measure the organisation's actual performance?

To answer these questions, permissions were obtained to access the actual annual records of selected hotels to extract the objective measures of IT investment and hotel performance. In all, six hotel general managers gave their permission to the researchers to search their company records. Actual figures of the hotels' investment in IT in the previous year were obtained, including hardware costs, software costs, IT training costs, user support costs, and total IT investment. Also, actual figures of the hotels' performance in the previous years were obtained, including the net financial return, hotel occupancy rate and the number of visitors to the hotel.

These actual values were compared with the subjects perception data obtained from the questionnaire by regressing the actual measures on the perception measures. Table 8 gives the results of regression analyses. The "R square" values are all greater than 0.77 , indicating that at least $77 \%$ of the variance in the actual measures can be accounted for the 
perception data. In fact, most of the items are above $90 \%$ showing a strong relationship between the two. This means, according to the actual data from the hotel records, the perception ratings by the employees could be considered to be reliable indicators for the variables under consideration.

Table 8: Regression of Actual Data on Employees' Perception

\begin{tabular}{|c|c|c|c|c|c|c|c|}
\hline Var & Question items & $\begin{array}{c}\text { R } \\
\text { Square }\end{array}$ & df & $\mathbf{F}$ & Sig. & $\begin{array}{c}\text { b0 } \\
\text { Constant }\end{array}$ & b1 \\
\hline \multirow[t]{5}{*}{ ITI } & Computer Hardware Costs (ITI-1) & 0.927 & 4 & 50.76 & 0.002 & 6.816 & $2.4 \mathrm{E}-09$ \\
\hline & Computer Software Costs (ITI-2) & 0.926 & 4 & 49.98 & 0.002 & 7.2189 & $3.9 \mathrm{E}-09$ \\
\hline & Costs of Training IT Users (ITI-3) & 0.962 & 4 & 102.60 & 0.001 & 6.293 & $1.5 \mathrm{E}-07$ \\
\hline & Costs of Supporting IT Users (ITI-4) & 0.771 & 4 & 13.47 & 0.021 & 6.847 & $3.2 \mathrm{E}-08$ \\
\hline & Total Costs of IT Investment (ITI-5) & 0.811 & 4 & 17.20 & 0.014 & 7.727 & $4.7 \mathrm{E}-10$ \\
\hline \multirow{3}{*}{$\mathrm{HP}$} & Financial Performance (ROI) (HP-1) & 0.897 & 4 & 34.66 & 0.004 & 7.2996 & 0.0174 \\
\hline & Occupancy Rates (HP-2) & 0.972 & 4 & 136.60 & 0.000 & 5.970 & 0.0301 \\
\hline & Number of Visitors (HP-3) & 0.933 & 4 & 55.68 & 0.002 & 7.079 & $1.9 \mathrm{E}-05$ \\
\hline
\end{tabular}

The regression relationships between the actual data and the employees' perception are illustrated in Figure 7. These graphs clearly show the close relationship between the actual and perception data. For the remainder of this paper, the perception measures will be used in subsequent analyses.

Figure 7: Regression of Actual Data on Perception Measures

Computer Hardware Costs

Perception Data (ITI-1)

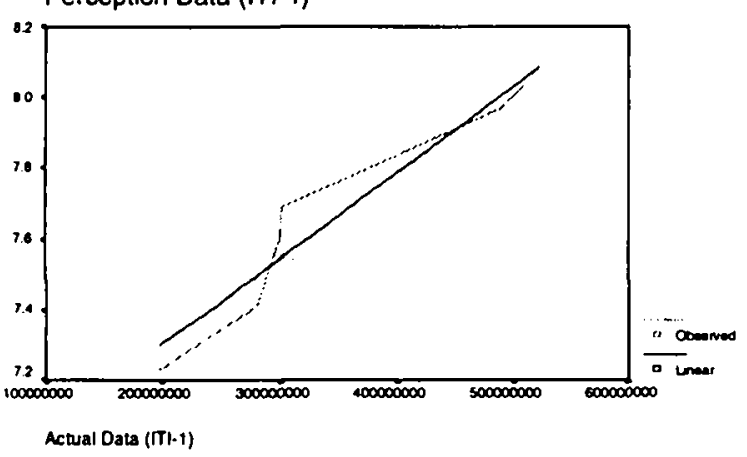

Costs of Training IT Users

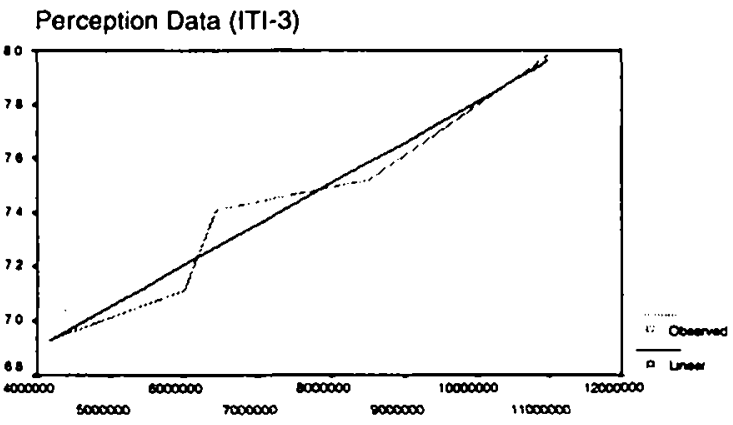

Actual Data (ITI-3)
Computer Software Costs

Perception Data (ITI-2)

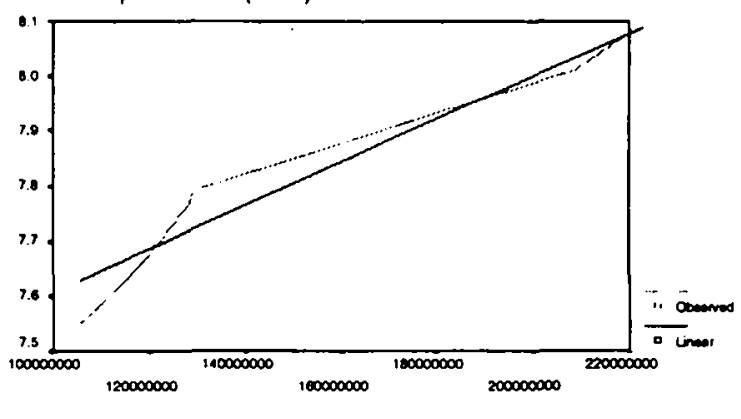

Actual Data (ITI-2)

Costs of Supporting IT Users

Perception Data (ITI-4)

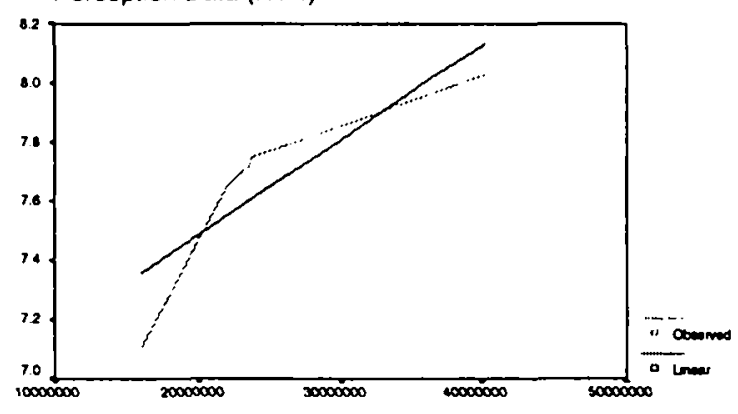

Actual Data (ITI-A) 
Total Costs of IT Investment

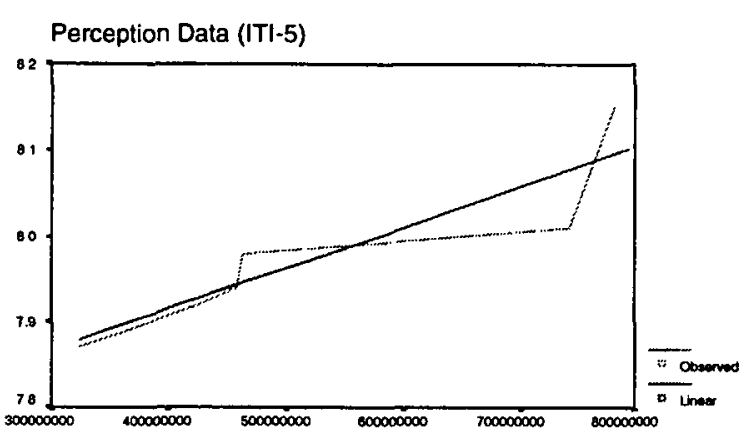

Actual Data (ITI-5)

Occupancy Rates

Perception Data (HP-2)

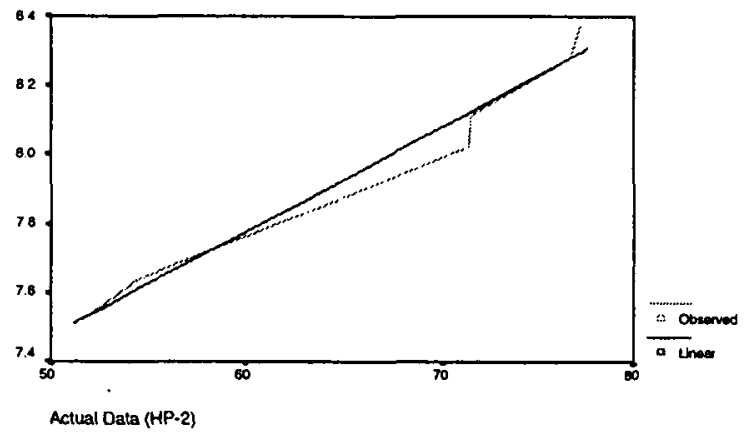

Financial Performance (ROI)

Perception Data (HP-1)

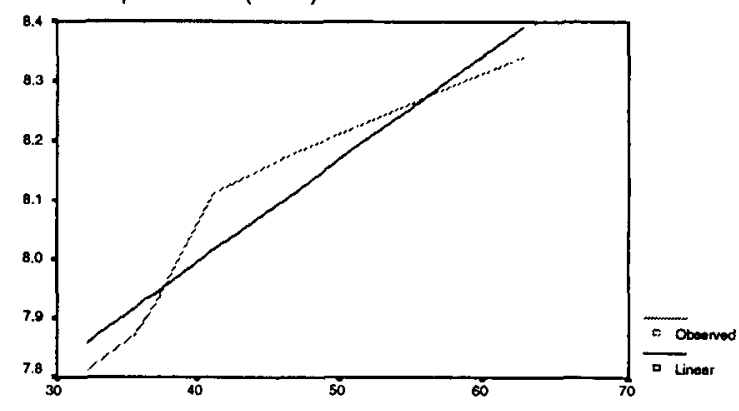

Actual Data (HP-1)

Number of Visitors

Perception Data (HP-3)

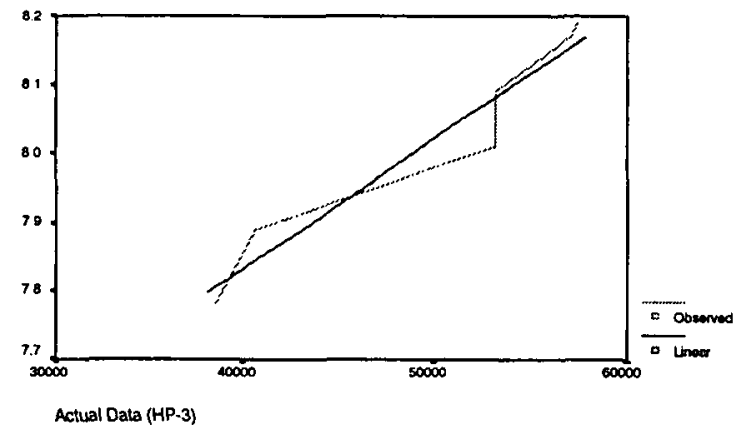

Here "actual data" is shown as the independent variable (X-axis), and "employee perception" is shown as the dependent variable ( $\mathrm{Y}$-axis).

Factor analyses were performed on each of the subscales. All five subscales were found to contain only 1 factor, indicating that each subscale is relatively homogeneous. This is not surprising because the subscales were constructed based on items selected from validated instruments in the literature for these variables. This means in subsequent analysis, one may use a single factor score rather than each individual item score.

\section{DEMOGRAPHIC DIFFERENCES AMONG RESPONDENTS' PERCEPTION}

The purpose of this section is to examine whether there are differences in the five dependent variables, viz. IT investment, IT usage, user satisfaction, employee performance, and hotel performance, with respect to groups in the category variables age, gender, position in hotel, education level, and individual income as independent variables. The factor scores of the dependent variables were used in the analysis. Some of the smaller frequencies in the original categories have been merged in the analysis.

First, a multivariate analysis of variances model was fitted for all five dependent variables with the five category variables as independent variables. Effects tested were main effects only, i.e. the tests for each effect was adjusted for possible confounding with all other effects in the model (they are unique effects). Post-hoc comparisons among the levels of variables showing significant effects were performed by means of the Bonferroni procedure (Hair et al., 1995). The results of the multivariate analysis are shown in Table 9.

Table 9: Test of Multivariate Significance

\begin{tabular}{||l|c|c|c|c||}
\hline \multicolumn{1}{|c|}{ Effect } & Wilk's Lambda & $\mathbf{F}$ & d.f & Sig. $\boldsymbol{~}$ \\
\hline \hline Age & 0.912 & 3.408 & 20,2419 & $\mathbf{P}=\mathbf{0 . 0 0 0}$ \\
\hline Gender & & & & \\
\hline Position in Hotel & 0.993 & 1.068 & 5,7290 & $\mathbf{P}=0.377$ \\
\hline Education Level & 0.947 & 1.986 & 20,2419 & $\mathbf{P}=\mathbf{0 . 0 0 6}$ \\
\hline Individual Income & 0.947 & 1.948 & 10,1458 & $\mathbf{P}=\mathbf{0 . 0 3 5}$ \\
\hline
\end{tabular}

Significant differences are shown in bold.

Significant differences (shown in bold in the table) in the set of dependent variables were found among the categories with respect to four of the five categories variables viz. age, position in hotel, education level and individual income. There were no significant differences between females and males. 
Univariate analyses of variance were then performed to identify the dependent variables on which independent variables had significant effects. The results of the univariate tests are shown in Table 10. An examination of the Table shows,

- different "age" groups differ significantly re their perception of the level of IT investment, user satisfaction and employee performance;

- different "individual income" groups differ significantly re their perception on the level of IT investment and hotel performance;

- different "position in hotel' groups differ significantly re their perception on the level of user satisfaction; and

- different "education level" groups differ significantly re their perception on the level of hotel performance.

Table 10: Test of Univariate Significance

\begin{tabular}{|c|c|c|c|c|}
\hline Dependent Variable & Effects & $F$ & d.f. & Sig. $\rho$ \\
\hline \multirow[t]{4}{*}{ IT Investment } & Age & 5.605 & 4,733 & $P=0.000$ \\
\hline & Position in hotcl & 2.226 & 4,733 & $P=0.065$ \\
\hline & Education & 0.233 & 2,733 & $\mathrm{P}=0.792$ \\
\hline & Individual Income & 5.671 & 4,733 & $P=0.000$ \\
\hline \multirow[t]{4}{*}{ IT Usage } & Age & 2.394 & 4,733 & $P=0.051$ \\
\hline & Position in hotel & 2.233 & 4,733 & $P=0.064$ \\
\hline & Education & 1.640 & 2,733 & $P=0.195$ \\
\hline & Individual Income & 2.375 & 4,733 & $\mathrm{P}=0.051$ \\
\hline \multirow[t]{4}{*}{ User Satisfaction } & Age & 4.443 & 4,733 & $P=0.001$ \\
\hline & Position in hotel & 3.049 & 4,733 & $P=0.017$ \\
\hline & Education & 0.343 & 2,733 & $P=0.710$ \\
\hline & Individual Income & 0.731 & 4,733 & $P=0.571$ \\
\hline \multirow{4}{*}{$\begin{array}{c}\text { Employee } \\
\text { Performance }\end{array}$} & Age & 4.285 & 4,733 & $P=0.002$ \\
\hline & Position in hotel & 1.082 & 4,733 & $\mathrm{P}=0.364$ \\
\hline & Education & 0.981 & 2,733 & $\mathrm{P}=0.375$ \\
\hline & Individual Income & 1.070 & 4,733 & $P=0.370$ \\
\hline \multirow[t]{4}{*}{ Hotel Performance } & Age & 2.061 & 4,733 & $\mathrm{P}=0.084$ \\
\hline & Position in hotel & 1.630 & 4,733 & $P=0.165$ \\
\hline & Education & 6.108 & 2,733 & $P=0.002$ \\
\hline & Individual Income & 2.806 & 4,733 & $P=0.025$ \\
\hline
\end{tabular}

Significant differences are shown in bold.

This appears to indicate that age has the widest significant influence affecting the respondents' perception in three out of the five dependent variables, while individual income level affects two dependent variables, and position in hotel and education level each only affects one.

However, there is no category variable which has a significant effect on IT usage. This suggests that an employee's age, position in hotel, education level and income do not affect their perception of the level of IT usage by that employee. This seems to indicate that the level of IT usage is more likely to be determined by the need of the tasks at hand rather than by any of these category variables.

Post-hoc test by the Bonferroni procedure were employed to identify which categories (or groups) of these independent variables differ significantly on the dependent variables identified above.

\section{Age effect}

In this section, the differences in employee perception for the different age groups will be examined in greater detail. The three research variables under consideration relates to the employees' perceptions of $I T$ investment, user satisfaction and employee performance. The results are summarised in Figure 8 below where the mean levels (deviation from the total mean) of each age group are plotted.

With respect to the employees' perception of the level of IT investment, both the youngest group, i.e. age "up to 24 years" and the oldest group, i.e. age " 56 years \& above", were found to be significantly higher than that of the three age groups in the middle. The perception of the oldest group was particularly positive. It is interesting to observer that even the actual level of IT investment is a relatively objective measure, the subjective perceptions of employees still differ significantly among the groups. This highlights the need for the senior managers to explicitly inform and properly promote awareness among their employees of their decisions to invest in TT resources for the organisation. 
One possible explanation of this difference in perception may be that the oldest group still remembers the former days when things are totally done manually and hence are grateful for the improvement they are now experiencing.

Next, it is observed that the mean user satisfaction level of the age group "up to 24 years" was significantly lower than both that of the age groups " $41-55$ years" and that of " 56 years above". The mean satisfaction levels of both the age

\section{Figure 8: Differences in Perception by Different Age Groups}

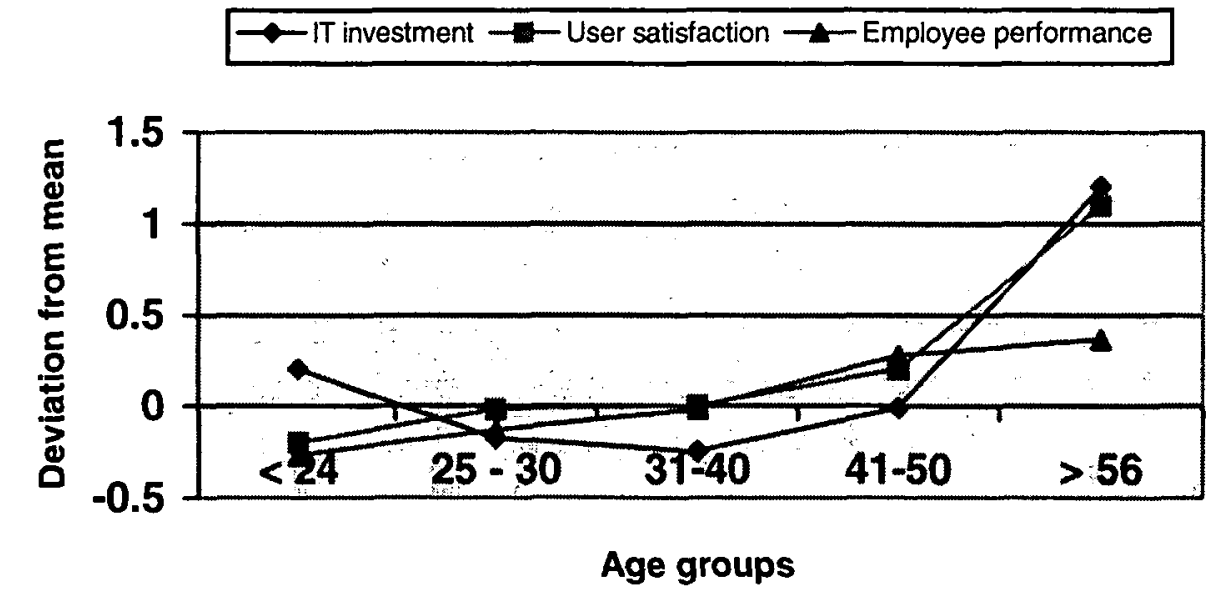

groups "25 to 30 years" and " 31 to 40 years" were significantly lower than that of "56 years above".

Generally speaking, the younger groups are less satisfied than the older groups. There is a clear trend from these data to indicate that the employees' perception of user satisfaction increases with increasing age. The variable being measured here is not general satisfaction, but the user satisfaction with the computer facilities or the company's information system. This seems to further support the earlier assumption that, the older group tends to "appreciate" the new technology more because it is likely that they started their working career in a less automated, and hence more administratively cumbersome work environment

Similarly it was found that the perception of the three younger age groups "up to 24 years", $25-30$ years, and "31-40 years" on employee performance were significantly lower than those of the older age groups "41-55 years" and " 56 year above". However the perceived differences were not as marked as in the previous two cases. This means the older employees had a more positive feeling about their level of performance than the younger ones.

These findings suggest a possible positive relationship among these three dependent variables, viz. IT investment, user satisfaction and employee performance. More positive perception of IT investment results in more positive user satisfaction. A more positive user satisfaction is associated with a more positive perception of employee performance. These relationships have been investigated and reported in greater details elsewhere (Sri Darma \& Lo 1998). 
Individual monthly income

In this section, the differences in employees perception with different income levels are being examined. As shown in Figure 9, significant differences were found among the different income groups on the perceived levels of IT investment and hotel performance.

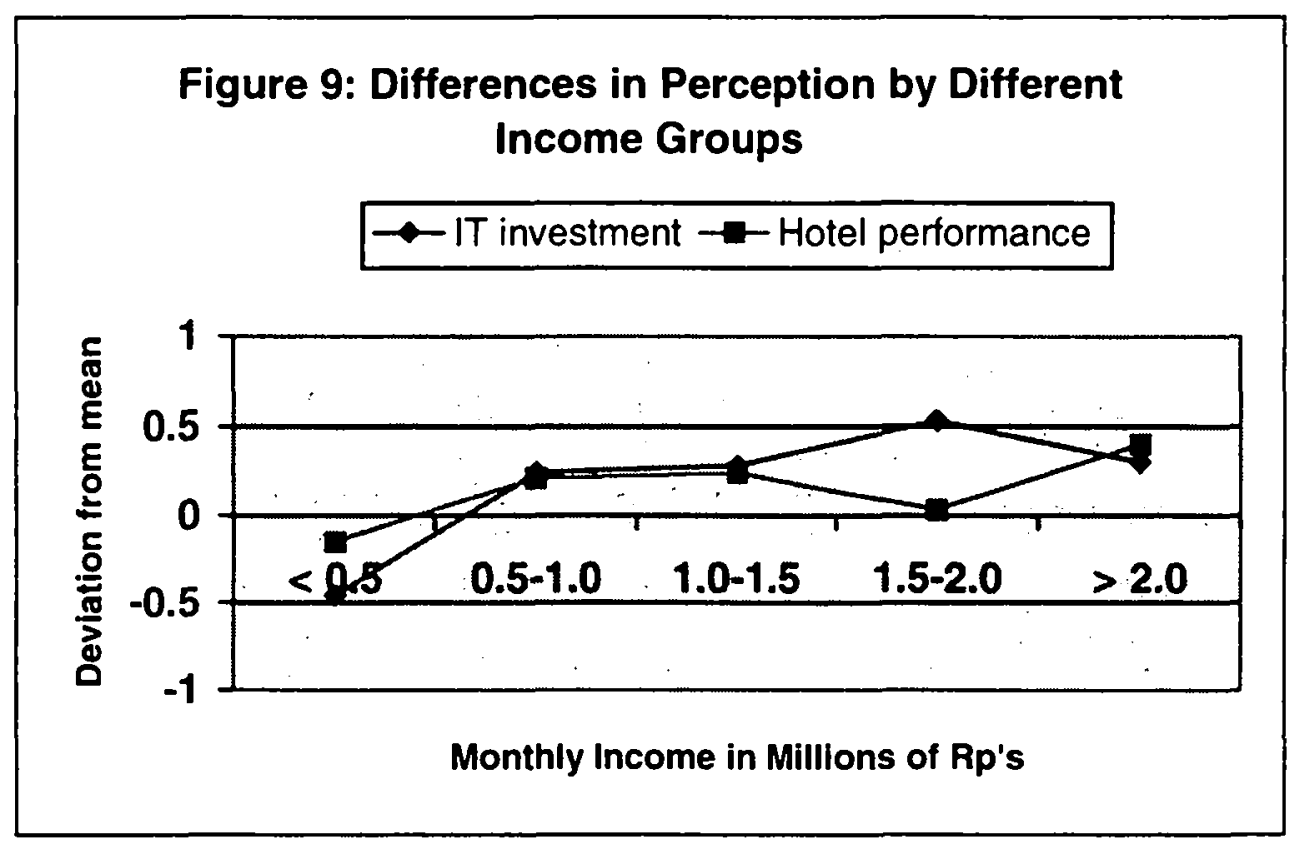

With the exception of the two highest income groups, the two series on perceived IT investment and hotel performance, were remarkably similar. Generally speaking, those in the higher income groups were more positive in their perception of the levels of IT investment by their hotel as well as the levels of hotel performance. However, there appears to be a "cross-over" in the transition from the second highest to the highest income groups. (The graph shows a "dip" on the right hand side.) There does not appear to be any logical explanation for this. It is also interesting to note that, the perception of the lower income group with "less than 500,000" Rps. per month, was found to be significantly less than any other groups. Generally speaking, as the monthly income increase, the perceived levels of IT investment and hotel performance also improves. As is in the case of the age effect, this also suggests a positive relationship between the amount of IT investment in an organisation and the perceived level of performance in that organisation.

\section{Position in hotel}

In this section, the differences in the perception of employees in different positions in the hotel (different job functions) are examined. Figure 10 shows the mean user satisfaction levels as perceived by employees who work in different departments of the hotel. 
One group stands out prominently in this analysis. The perceived user satisfaction level of those working in the accounting/finance department was significantly higher than the satisfaction levels of employees who work in the other sections in the hotel. Their satisfaction levels were even higher than those working in the Information Systems department, which ranked second in this comparison. This probably reflects the reality that computing facilities have been traditionally used to support mainly the accounting/finance functions in hotels. It is only in relatively recently years that other applications of the computers have been explored in other job functions in an organisation. This seems to indicate that familiarity or greater experience with computers is often associated with greater use satisfaction (and less

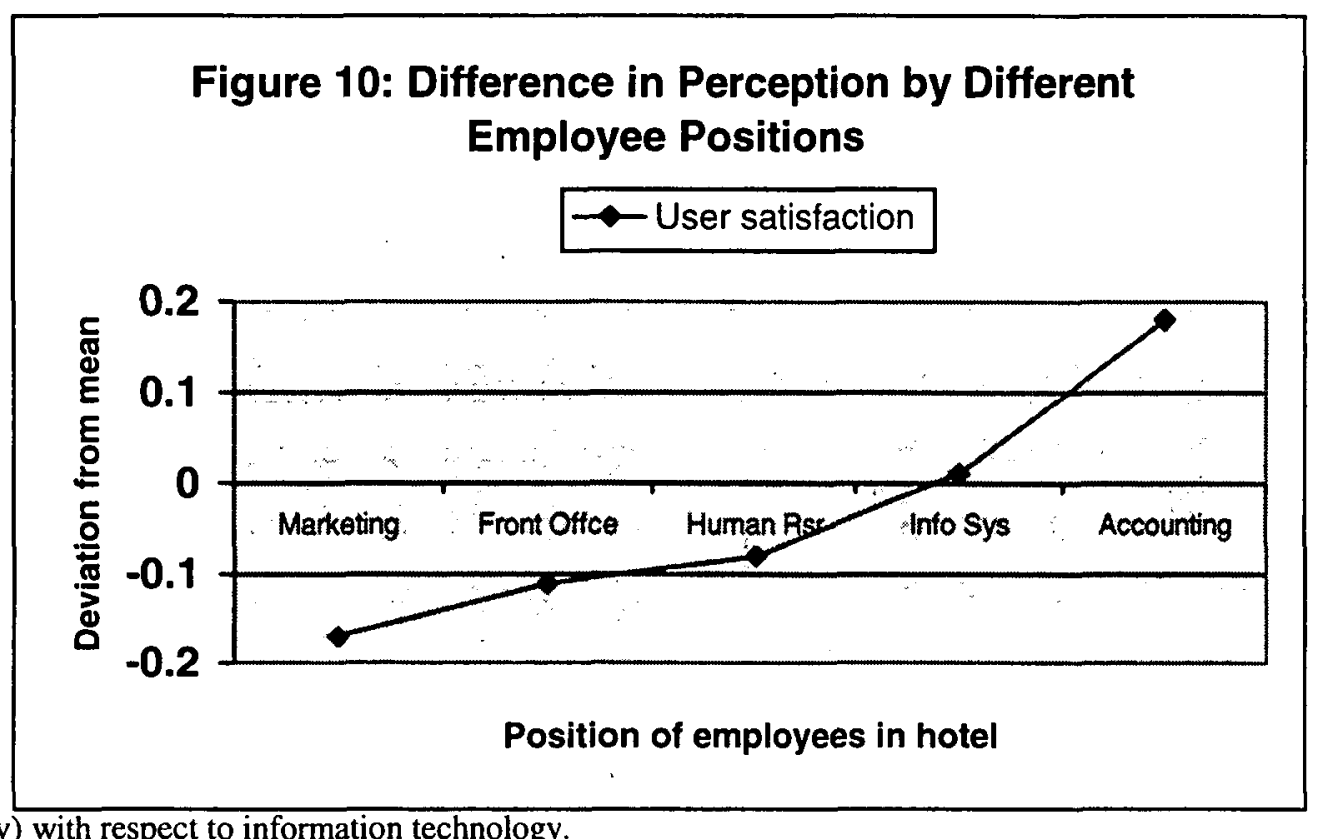

anxiety) with respect to information technology.

On the other hand, the low user satisfaction level of the marketing group is probably related to the relatively low penetration of IT in the marketing function in these organisations.

\section{Educational Levels}

With respect to educational level, there were significant differences found in the employees' perception on hotel performance (See Figure 11). It appears that the higher the level of education of the employees, the less positive is their perception on the level of hotel performance. This may be attributed to the more critical attitudes and higher expectation level that are often associated with university graduates.

Figure 11: Differences in Perception by Different Education Levels

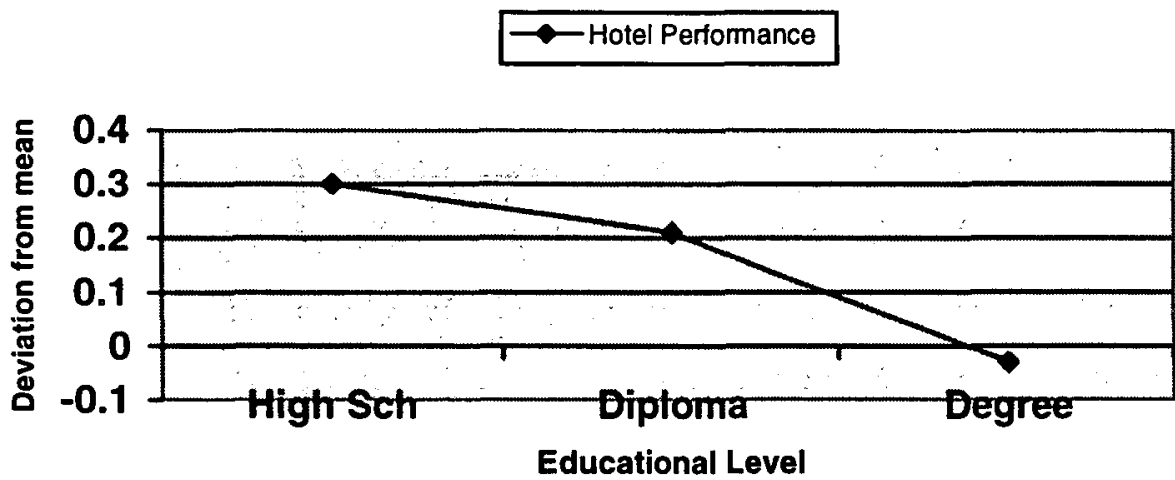




\section{RELATIONSHIPS AMONG THE USER-ORGANISATION VARIABLES}

In this section the relationship between the five research variables, viz. information technology investment (ITI), information technology usage (ITU), user satisfaction (US), employee performance (EP), and hotel performance (HP) will be examined.

A correlation analysis was performed to explore the strengths of the relationship between pairs of variables. Table 11 summarizes the Pearson Product-moment correlation coefficients between each pair among the five variables:

Table 11: Pearson Product-Moment Correlation between Pairs of Variable

\begin{tabular}{|c|c|c|c|c|c|}
\hline & ITI & ITU & US & EP & HP \\
\hline ITI & 1.000 & & & & \\
ITU & 0.203 & 1.000 & & & \\
US & 0.261 & 0.387 & 1.000 & & \\
EP & 0.286 & $\mathbf{0 . 5 4 9}$ & $\mathbf{0 . 5 8 8}$ & 1.000 & \\
HP & 0.376 & 0.341 & 0.402 & 0.465 & 1.000 \\
\hline
\end{tabular}

All correlation coefficients are significant at the 0.01 level.

While all variables are significantly and positively correlated at the 0.01 level, a closer examination of the table reveals that the strength of correlation appears to fall into three groups:

- Relatively strongly correlated with coefficient of determination $r^{2}>30 \%$ : viz. EP \& ITU (0.549), and EP \& US (0.588). These are indicated in bold in Table 11.

- Moderately correlated with $10 \%<r^{2}<20 \%$ : viz. HP \& ITU $(0.341)$, HP \& ITI $(0.376)$, US \& ITU $(0.387)$, and HP \& US (0.402). These are indicated in italic in Table 11.

- Weakly correlated with $r^{2}<10 \%$ : viz. ITI \& ITU $(0.203)$, ITI \& US $(0.261)$, and ITI \& EP $(0.286)$.

Three observations may be made from the results so far. Firstly, the strongest relationship is among the three variables: information technology usage (ITU), user satisfaction (US) and employee performance (EP). This appears to suggest that there is a strong belief among the employees that their performance is enhanced by higher computer usage and their satisfaction with the organisation's information system. This relationship will be explored further later in this section by regression analysis. The second observation is that, information technology investment (ITI), while is moderately related to hotel performance (HP), correlates only rather weakly with three (ITU, US, EP) out of the other four variables. This weak relationship may account for the reason why past research in linking IT investment to organisational performance sometimes led to inconclusive/ambivalent results. The third observation is that, hotel performance (HP) appears to be roughly equally correlated to each of the other four variables (ITI, ITU, US \& EP). This seems to imply that none of these variables taken singly (That includes $I T$ investment as well) can fully account for the variation in hotel performance. This supports the earlier argument that in order to fully leverage the IT capabilities of an organisation, managers must also pay attention to fostering other aspects of the organisation-employee relationships.

To further clarify these observations, several multiple regression analyses were performed. The results are reported below.

\section{Determinants of Employee Performance}

In relation to the first observation mentioned above, a multiple linear regression analysis was performed by regressing employee performance (EP) on information technology usage (ITU) and user satisfaction (US). The results are shown in Table 12. 
Table 12: Regression of Employee Performance on ITU \& US

\begin{tabular}{|c|c|c|c|c|}
\hline & \multicolumn{2}{|c|}{ Regression Coefficient } & \multirow[b]{2}{*}{ Constant } & \multirow[b]{2}{*}{ Other statistics } \\
\hline $\begin{array}{c}\text { Dependent } \\
\text { Variable }\end{array}$ & $\begin{array}{c}\text { Information } \\
\text { technology usage } \\
\text { (ITU) }\end{array}$ & $\begin{array}{c}\text { User satisfaction } \\
\text { (US) }\end{array}$ & & \\
\hline $\begin{array}{c}\text { User Performance } \\
\text { (UP) }\end{array}$ & $\begin{array}{c}0.378 \\
(t=14.654)\end{array}$ & $\begin{array}{c}0.441 \\
(t=17.111)\end{array}$ & $\begin{array}{c}1.632 \mathrm{E}-16 \\
\text { (effectively } \\
\text { zero) }\end{array}$ & $\begin{array}{l}R=0.68 \\
R^{2}=0.47\end{array}$ \\
\hline $\begin{array}{l}\text { Regression } \\
\text { equation }\end{array}$ & \multicolumn{3}{|c|}{$U P=0.378 I T U+0.441 U S+$ error } & $F=412.58$ \\
\hline
\end{tabular}

Significant at 0.01 level

This analysis shows that both information technology usage and user satisfaction contribute positively to employee performance. But the effect of user satisfaction is greater than that of information technology usage. This indicates that psycho-social factors such as user satisfaction with the organisational information system, are more important determinant of employee performance than the objective measures such as actual IT usage. Therefore it is not sufficient to just provide access to IT use. It is very important to ensure that employees are satisfied (or feel satisfied) with the IT facilities provided.

\section{What affects Hotel Performance?}

The next analysis investigates the main determinants of hotel performance. The results of the regression of hotel performance (HP) on information technology investment (ITI) and employee performance (EP) are shown in Table 13.

Table 13: Regression of Hotel Performance on ITI \& EP

\begin{tabular}{|c|c|c|c|c|}
\hline & \multicolumn{2}{|c|}{ Regression Coefficient } & \multirow[b]{2}{*}{ Constant } & \multirow[b]{2}{*}{ Other statistics } \\
\hline $\begin{array}{l}\text { Dependent } \\
\text { Variable }\end{array}$ & $\begin{array}{c}\text { Information } \\
\text { technology investment } \\
\text { (ITI) }\end{array}$ & $\begin{array}{c}\text { Employee } \\
\text { performance (EP) }\end{array}$ & & \\
\hline $\begin{array}{l}\text { Hotel Performance } \\
\text { (HP) }\end{array}$ & $\begin{array}{c}0.264 \\
(t=9.167)\end{array}$ & $\begin{array}{c}0.390 \\
(t=13.514)\end{array}$ & $\begin{array}{c}1.932 \mathrm{E}-16 \\
\text { (effectively } \\
\text { zero) }\end{array}$ & $\begin{array}{l}\mathrm{R}=0.53 \\
\mathrm{R}^{2}=0 . .28\end{array}$ \\
\hline $\begin{array}{l}\text { Regression } \\
\text { equation }\end{array}$ & \multicolumn{3}{|c|}{$H P=0.264 I T I+0.390 E P+$ error } & $F=183.92$ \\
\hline
\end{tabular}

Significant at 0.01 level

While both IT investment and employee performance significantly and positively affect hotel performance. The effect of employee performance is greater than that of IT investment. This is to be expected, as intuitively speaking, one would expect the impact of employee performance is more direct. IT investment can affect hotel performance only in an indirect way.

\section{What affects IT usage?}

To examine what affects information technology usage (ITU) in an organisation, a multiple linear regression analysis was performed by regressing ITU on information technology investment (ITI) and user satisfaction (US). The results are shown in Table 14. 
Table 14: Regression of IT usage on ITI \& US

\begin{tabular}{|c|c|c|c|c|}
\cline { 2 - 4 } \multicolumn{1}{c|}{} & \multicolumn{2}{c|}{ Regression Coefficient } & \multicolumn{1}{c|}{} \\
\hline $\begin{array}{c}\text { Dependent } \\
\text { Variable }\end{array}$ & $\begin{array}{c}\text { Information } \\
\text { technology investment } \\
\text { (ITI) }\end{array}$ & $\begin{array}{c}\text { User satisfaction } \\
\text { (US) }\end{array}$ & Constant & Other statistics \\
\hline $\begin{array}{c}\text { Information } \\
\text { technology usage } \\
\text { (ITU) }\end{array}$ & $\begin{array}{c}0.110 \\
(\mathrm{t}=3.557)\end{array}$ & $\begin{array}{c}0.358 \\
(\mathrm{t}=11.590)\end{array}$ & $\begin{array}{c}2.935 \mathrm{E}-16 \\
\text { (effectively } \\
\text { zero })\end{array}$ & $\begin{array}{c}\mathrm{R}=0.40 \\
\mathrm{R}^{2}=0.16\end{array}$ \\
\hline $\begin{array}{l}\text { Regression } \\
\text { equation }\end{array}$ & \multicolumn{2}{|c|}{$I Y U=0.110$ ITU + 0.358 US + error } & $\mathrm{F}=90.40$ \\
\hline
\end{tabular}

Significant at 0.01 level

The interesting finding here is how (relatively) small the regression coefficient of information technology investment (ITI) is compared to that of user satisfaction (US). This confirms our earlier assertion that in order to maximise the potential of the IT capabilitics of an organisation, simply raising the level of IT investment, essential it may be, is not enough. Senior manager must do what they can to raise the satisfaction level of the users to ensure better utilisation of the IT capabilities. This highlights the importance of continuing post installation support of IT users to improve user satisfaction.

\section{SUMMARY AND DISCUSSION}

The perception of employees on the organisational impacts of investment in Information Technology by the organisation is crucial to the success or failure of such an investment. In this paper, the demographic variations in employees' perception in five organisation-user variables, viz. investment in IT, level of IT usage, user satisfaction with IT, employee performance, and hotel performance, and the interrelationships among them were examined.

In the two cases where objective data were available, employee perception measures were found to be reliable indicators of the actual level of IT investment and hotel performance. It is therefore assumed that perceptual measures may be used to provide a reasonable representation of the actual measures in these two areas.

Age was found to account for significant variations in the perceived level of organisational $I T$ investment, user satisfaction with IT facilities, and perceived employee performance level. The older the employee the more likely is their perception to be more positive. The only exception is the case of $\Gamma T$ investment, where the youngest group also have a significantly more positive perception. The fact that there were significant differences in perception among the different age groups highlights an important point. Even though the amount of IT investment in an organisation can be objectively measured, the perceptions of the different individuals may still differ. It is important for senior managers not to neglect explicitly informing the employees of investment decisions so that they may be more aware of what actually took place in their organisation.

The age differences in the perceived level of user satisfaction with the IT facilities could be due to the "contrast effect", because older employees are likely to compare the relative ease of doing their tasks in the current computerised environment with the early days where all tasks had to done manually. Thus they are more positively oriented toward the organisation's information systems (which may also be more user friendly compared to the early days).

The age differences in the perception of employee performance, though much smaller than the previous two, are a bit more difficult to explain. Nevertheless the results in the current study seems to suggest a "positive" age effect in these perception measures.

The different perception of the different income groups presented a more intriguing situation, as the positive perception measures did not follow a "monotonically increasing" trend at all income levels, particularly at the higher income end. However, both the IT investment level and the hotel performance level, were perceived to be the lowest by the lowest income group. This may have to do with the fact that employees at the lowest income group are likely to have the least affinity with the organisation and hence perceived these two variables in the least favourable light.

The effect of the employee's position in the organisation provides a rather interesting trend. Those employees in positions that expose them to more computer usage or that had the history of longest exposure to computers, tend to have a higher level of user satisfaction than employees from other areas. Thus Accounting department employees are the most satisfied followed by the Information Systems (IS) department employees. It is interesting to observe that the IS employees did not have the highest level of user satisfaction. It is not clear whether this is due to the possibility that in many hotels, the Account office is better equipped than the IS department, or whether this is due to the higher expectation of the IS staff. Further research is needed to determine the real reason.

However, employees in the Human Resources departments, the "Front" offices, and the Marketing departments in these 
hotels have a much lower user satisfaction level, with the Marketing employees have the lowest of them all. This highlights the need to expand the use of IT facilities to these applications areas. The findings here support the generally accepted concept that the longer a person's experience with using the computer will reduce computer anxiety and improve one's attitude to computer usage which ultimately leads to better user performance (Igbaria \& Tan 1997).

Finally, it was observed that the perception of hotel performance decreases as the education level of the employee increases. This is probably due to the higher expectation of the employees as their educational level increases. Presumably they are taught to think more critically and independently.

Results of correlation and regression analyses in the present study clearly demonstrated the existence of close relationships among the five research variables: ITI, ITU, US, EP and HP. In particular the level of employee performance (EP) is strongly affected by user satisfaction and IT usage, both combined together accounts for close to $50 \%$ of the variances. This clearly highlights that the attitude of employees (US) and the hands-on factor (ITU) are most critical to the employee performance, more so than the original IT investment itself.

Both employee performance (EP) and IT investment (ITI) were found to contribute significantly to the level of hotel performance (HP), accounting for nearly $30 \%$ of the variance in the latter. However, the effect of employee performance (EP) was again found to have a greater effect than IT investment. Similar results were obtained when IT usage (ITU) was regressed onto IT investment (ITI) and user satisfaction (US). Again the US was found to have a stronger influence on ITU than ITI. These results confirm the importance of the attitudinal factors such as user satisfaction when one examines the impact of IT investment in organisations.

The findings thus far suggest a rather complex relationship among the five research variables, requiring further investigation. This shall be the subject of a separate path analysis and/or structured equation modeling study to be reported in a forthcoming paper. However, based on results obtained thus far, it is possible to conclude that, when managers consider the decision to invest in information technology in an organisation, it is important to cultivate and nurture a sense of "user satisfaction" among the employees with the IT systems. Otherwise it would be difficult to fully leverage the potential of the IT capabilities as a result of the investment. Mere putting more money in IT equipment or software, dose not necessarily lead to increased usage of IT systems, let alone ultimate employee or hotel performance. The need to attend to the human side of information systems can never be over emphasised.

\section{REFERENCES}

Banker, R.D., Kauffman, R.J. and Morey, R.C. (1990) "Measuring gains in operational efficiency from information technology: a study of positran deployment at Hardee's Inc.”, Journal of MIS, Vol 6, No 2, pp 59-81.

Bender, D. (1986) "Financial impact of information processing", Journal of MIS, Vol 3, No 2, pp 232-248.

Byrd, T.A. and Marshall, T.E. (1997) "Relating information technology investment to organisational performance: A causal model analysis", Omega, Vol 25, No 1, pp 43-56.

Cron, W. and Sobol, M. (1983) "The relationship between computerization and performance: a strategy for maximizing economic benefits of computerization", Information and Management, Vol 6, pp 171-181.

Cronbach, W. and Meehl, P.E. (1981) Construct validity in psychological testing. In Mason, R.O. and Swanson, B.E. (editors.), Measurement for Management Decision, Reading, M.A: Addison Wesley, pp. 335-359.

DeLone, W.H. and McLean, E.R. (1992) "Information systems success: The quest for the dependent variable", Information Systems Research, Vol 3, No 1, pp 60-95.

Doll, W. J. and Torzadech, G. (1988) "The measurement of end-user computing satisfaction", MIS Quarterly, Vol 12, No 2, pp 259-274.

Fitzgerald, G. (1998) "Evaluation information systems projects: A multidimensional approach", Journal of Information Technology, Vol 13, No 1, pp 15-27.

Floyd, S.W. and Wooldridge, B. (1990) "Path analysis of the relationship between competitive strategy, information technology and financial performance", Journal of Management Information Systems, Vol 13, No 1, pp 1527.

Hair, J.R. Anderson, R.E., Tathan, R.L. and Black, W.C. (1995) Multivariate Data Analysis, Englewood Cliffs, NJ: Prentice-Hall.

Harris, S.E. and Katz, J.L. (1991) "Organizational performance and information technology investment intensity in the insurance industry", Organization Science, Vol 2, No 3, pp 263-295.

Hitt, L.M. and Brynjolfsson, E. (1996) "Productivity, business profitability and consumer surplus: Three different measures of information technology value", MIS Quarterly, Vol 20, No 2, pp 121-142.

Igbaria, M. and Tan, M. (1997) "The consequences of information technology acceptance on subsequent individual performance", Information and Management, Vol 32, No 3, pp 113-121.

Jeffrey, D. and Hubbard, N.J. (1994) "A model of hotel occupancy performance for monitoring and marketing in the hotel industry", International Journal of Hospitality Management, Vol 13, No 1, pp 57-71.

Kauffman, R.J. and Weill, P. (1989) "An evaluative framework for research on the performance effects of information technology investment", Proceedings of Tenth International Conference on Information Systems, Boston, USA, pp. 198-218.

Kerlinger, F.N. (1986) Foundations of Behavioural Research, New Yourk: Holt, Rhinehart and Winston. 
Lubbe, S., Parker, G. and Hoard, A. (1995) "The profit impact of IT investment", Journal of Information Technology, Vol 10, No 1, pp 44-51.

Mahmood, M.A. (1994) "Evaluating organizational efficiency resulting from information technology investment: An application of data envelopment analysis", Journal of Information Systems, Vol 4, No 2, pp 95-115.

Mahmood, M.A. (1997) "How information technology resources affect organizational performance and productivity", Information Resources Management Journal, Vol 10, No 1, pp 4-5.

Mardani, N.L.K. (1997) Bali dalam Angka Semester I tahun 1997, Department of Bali Tourism, Post and Telecommunication, Denpasa, Bali, Indonesia.

Mata, F.J., Fuerst, W.L. and Barney, J.B. (1995) "Information technology and sustained competitive advantage: A resource-based analysis", MIS Quarterly, Vol 19, No 4, pp 487-505.

Mukhopadhyay, T., Kekre, S. and Kalathur, S. (1995) "Business value of information technology: A study of electronic data interchanges", MIS Quarterly, Vol 19, No 2, pp 137-156.

Nunnally, J.C. (1978) Psychometric Theory, New York: McGraw-Hill.

Orlikowski,, W.J. and Baroudi, J.J. (1991) "Studying information technology in organizations: research approaches and assumptions", Information Systems Research. Vol 2, No 1, pp 1-28.

Parthasarthy, R and Sethi, S.P. (1993) "Relating strategy and structure to flexible automation: A test of fit and performance implications", Strategic Management Journal, Vol 14, No 4, pp 529 -549.

Powell, T.C. and Dent-Micallef, A. (1997) "Information technology as competitive advantage: The role of human, business, and technology resources", Strategic Management Journal, Vol 18, No 5, pp 375-405.

Rai, A., Patnayakuni, R. and Patnayakuni, N. (1997) "Technology investment and business performance", Communications of the ACM, Vol 40, No 7, pp 89-97.

Raymond, L., Pare, G. and Bergeron, F. (1995) "Matching information technology and organisational structure: an empirical study with implications for performance", European Journal of Information Systems, Vol 4, No 1, pp 3-16.

Roach, S.S. (1988) "Technology and the service sector: the hidden competitive challenge", Technology Forecasting and Social Change, Vol 34, No 4, pp 387-403.

Santos, D.W.L., Peffers, K. and Mauer, D.C. (1993) "The impact of information technology investment announcements on the market value of the firm", Information Systems Research, Vol 4, No 1, pp 1-23.

Sohal, A.S. and $\mathrm{Ng}$, L. (1998) "The role and impact of information technology in Australian business", Journal of Information Technology, Vol 13, No 3, pp 201-217

Sri Darma, G. and Lo, B.W.N. (1998) Information Technology and Organisational Performance: a survey of the hospitality inudstry. Working Paper SOMIT 98/1, School of Multimedia and Information Technology, Southern Cross University, Lismore, NSW, Australia.

Sriram, V., Stump, R.L. and Banerhee, S. (1997) "Information technology investments in purchasing: an empirical study of dimensions and antecedents", Information and Management, Vol 33, No 2, pp 59-72.

Strassmann, G. (1985) Information Payoff, New York: Free Press.

Straub, D., Limayem, M., and Karahanna-Evaristo, E. (1995) "Measuring system usage implications for IS theory testing", Management Science, Vol 41, No 8, pp 1328-1342.

Turner J.A. (1985) Organisational performance, size and the use of data processing resources. Working Paper \#58, Center for Research in Information Systems, New York University, New York.

Weill, P. (1992a) Managing the IT investment pyramid for competitive advantage, Graduate School of Management, The University of Melbourne, Australia.

Weill, P. (1992b) "The relationship between investment in information technology and firm performance: A study of the valve manufacturing industry", Information Systems Research, Vol 3, No 4, pp 307-333.

Willcocks, L. (1994) Information Management: The evaluation of information systems investments. London : Chapman \& Hall.

Willcocks, L. (1996) Investing in Information Systems, London: Chapman \& Hall. 